\title{
Current trends of investment climate impact on economic growth
}

\author{
Liliya Faridovna Zulfakarova, \\ Kazan Federal University, Institute of Management, \\ Economics and Financeuthors \\ KFU, IMEF \\ Kazan, Russia \\ e-mail: zulfakarova@mail.ru \\ Landysh Adgamovna Gadelshina \\ Kazan Federal University, Institute of Management, \\ Economics and Financeuthors \\ KFU, IMEF \\ Kazan, Russia \\ e-mail: lgadelshina@yandex.ru
}

\author{
Tina Muratovna Vakhitova \\ Kazan Federal University, Institute of Management, \\ Economics and Financeuthors \\ KFU, IMEF \\ Kazan, Russia \\ e-mail: tvahitov@yandex.ru \\ Liliya Fuatovna Garifova \\ Kazan Federal University, Institute of Management, \\ Economics and Financeuthors \\ KFU, IMEF \\ Kazan, Russia \\ e-mail: lgarifova@mail.ru
}

\begin{abstract}
The article focuses on the role of investment in justifying the prospects for economic development in the context of the transition to sustainable economic growth of the Russian economy. Without assessing the role of the investment resource, it is impossible to determine the strategies for the country's social and economic development, to develop and implement national, sectoral and regional programs. At the same time, foreign investment as an integral part of an open and effective international economic system is one of the catalysts for the growth of the economy, which is a consequence of globalization processes. In financial resources-constrained environment, the formation of a favorable investment climate, attracting investment in the country's economy as a whole has a positive impact; its rational use affects the competitiveness of domestic goods, the introduction and assimilation of new technologies, and the growth and development of production. The need for large investments in the Russian economy has been identified, which involves expanding the scope of investment activity and changing its structure in accordance with innovative priorities, without which qualitative economic growth is impossible. The Russian economy opened its domestic markets when it moved to the market economy model, but it proved to be uncompetitive that led to a further raw-material orientation of Russian exports. The rejection of the export-raw-material model is a theoretical and practical task, which requires withdrawal from the existing investment model. One should form such a model that meets the strategic tasks of the country, provides innovative development and modernization of the economy, forms a progressive type of reproduction and meets the vital needs of the Russian economic model. Active combination of innovative and investment processes can provide qualitative changes in the economy.
\end{abstract}

Keywords-investment climate; economic growth; foreign investment;

\section{INTRODUCTION}

During the crisis and post-crisis periods, the problem of economic growth takes a central place in economic discussions and publications. The transition to sustainable economic growth depends on a large-scale inflow of investment in various sectors of the Russian economy. Amid the improving of quantitative indicators in Russia and in some of its regions, there is a deterioration in the structural parameters that characterize the quality of economic growth and determine the place of the national economy in the world economy [10]. "The Russian economy is in a state of structural and technological imbalances that is characterized by a disproportionate distribution of factors of production and financial resources. To eliminate such disproportions, a specialized structural investment policy is needed" [7]. The effective investment policy is aimed to increase the investment attractiveness of regions, branches of the real economy and social sphere.

\section{Problem Statement}

Acceleration of economic growth is the main task for modern Russia. Today the development of the Russian economy is characterized by a number of contradictions that forms a complex dialectic of the resulting strategy understanding of financing economic growth in the country [9]. To justify the possibilities for economic development of the country, regions, individual industries, it is necessary to assess the role of the investment resource. Restructuring, following a large-scale privatization process in the countries of Central and Eastern Europe with transition economies were driven by political and institutional changes, not market forces [2]. Up to the present moment, it failed to restore the pre-crisis level of intensity of investment integration in the global 
economy as a whole and in some countries, in particular, in Russia [6].

Considering the positive and negative aspects of the impact of foreign capital on the development of the Russian economy, it should be noted that foreign investors are not ready to invest in the Russian economy. Russia is a large country that is rich in natural resources, has a well-educated labor force and a great market potential. However, Russia is one of the least attractive countries for investing [1].

The investment model of the development of Russia should have the following characteristics: the focus of the investment process on the new industrialization and innovation of the national economy, the combination of technological renewal, structural adjustment of the economy and change in the type of reproduction, to ensure sustainable and high-quality economic growth; high rate of capital accumulation; ensuring a new structure and quality of investments; maintaining the high role of domestic investment demand, using predominantly domestic resources, ensuring the unity of the country's investment space and national investment security $[10,11]$.

Many economists and scientific schools have studied issues of the content, structure and dynamics of investment, sources of its financing, the role in the functioning of the market economy. Development research in this direction is also conducted in Russia. In this connection, we can mention the works of Granberg A.G., Ivanter V.V., Klotsvog F.N., Kotlyar E.A., etc. [4, 5]. The works of K.A. Khubiev contain a general statement of the question of non-traditional sources of investment [8]. A number of authors (B.T. Kuznetsov, B.K. Sabanchieva) replace the concept of non-traditional investment sources with mixed $[12,13,16]$.

\section{RESEARCH QUESTIONS}

During the research, the authors are faced with a number of questions. What is the impact of foreign investment on the development of the real sector of the economy? Is Russia at the moment one of the most attractive countries for investing foreign capital? Can foreign investment influence the national economy in accordance with the objectives of foreign investors? What should be done to ensure that the country has a stable investment climate?

\section{PURPOSE OF THE STUdY}

The goal is to study the processes of attracting foreign investment in the Russian economy, affecting the country's economic growth in the rapidly changing political and economic conditions. To achieve this goal, the following set of tasks was formulated:

1. To identify the main forms and branch structure of foreign investment.

2. To identify factors that negatively affect the process of attracting foreign investment.

3. To determine the reasons of Russia's unattractiveness for foreign investors.
4. To fulfil the potential of foreign direct investment for the investors in terms of the possibility of full ownership of the company invested.

\section{RESEARCH METHODS}

According to the 2015 Foreign Direct Investment Confidence Index (FDICI) of A.T. Kearney, Russia ranked 11 th in the rating of the confidence index for foreign direct investment, and in 2016 - could not get into TOP-25 (Table 1 ) [15]. To study this problem, it is necessary to consider the reasons for Russia's unattractiveness for foreign investors. In the annual ranking for favorable business conditions DoingBusiness (compiled by the World Bank) for 2017, Russia is on the 40th place, while in 2013 it occupied 92nd place, in 2014 - 62nd, in 2015 - 54th, in 2016 - 51st [17].

TABLE I. FOREIGN DIRECT INVESTMENT CONFIDENCE INDEX FOR 2013-2016

\begin{tabular}{|c|c|c|c|c|}
\hline \multirow{2}{*}{ Country } & \multicolumn{5}{|c|}{ Ranking } \\
\cline { 2 - 5 } & 2013 & 2014 & 2015 & 2016 \\
\hline USA & 1 & 1 & 1 & 1 \\
\hline China & 2 & 2 & 2 & 2 \\
\hline UK & 8 & 4 & 3 & 5 \\
\hline Canada & 4 & 3 & 4 & 3 \\
\hline Germany & 7 & 6 & 5 & 4 \\
\hline Brazil & 3 & 5 & 6 & 12 \\
\hline Japan & 13 & 19 & 7 & 6 \\
\hline France & 12 & 10 & 8 & 8 \\
\hline Mexico & 9 & 12 & 9 & 18 \\
\hline Australia & 6 & 8 & 10 & 7 \\
\hline India & 5 & 7 & 11 & 9 \\
\hline Russia & 11 & - & - & - \\
\hline & & & & \\
\hline
\end{tabular}

World Bank includes 10 evaluation indicators: simplicity of business registration (Russia ranked 26th), taxation (45th), level of investor protection (53rd), and others.

Also there is a high level of branch administrative barriers. For example, for the construction of one building in Russia, it is necessary to collect more than 50 documents, while in Singapore, only 11 documents will be required.

Among the unfavorable conditions for foreign investors, it is possible to single out the high cost of borrowed funds, rather strict dependence of Russia on its own oil, which is one of the main sources of its budget revenues. According to the theory of the investment development path, there is a correlation between the country's net direct investments and the level of its economic development [18]. In the Russian economy, foreign investments are attracted, first of all, to those sectors in which foreign investors are interested. Over the past few years, the leading industries with foreign investment have become: manufacturing, mining, wholesale and retail trade, household products and personal items (Table 2). According to the World Bank, in 2012, \$25,345 million of 
direct investment was invested in processing industries, which is \$ 6,668 million higher than in 2016. However, in 2014 there was a high interest of foreign investors in this industry and the amount of investments amounted to 51,750 million dollars. The extraction of minerals in 2016 amounted to 17,426 million dollars. During the analyzed period, the highest amount of direct investment in this sector was observed in 2014 and amounted to 26,155 million dollars. In the construction sector there is a decline in foreign investment, so in 2012, foreign direct investment amounted to $\$ 5,303$ million, and in 2016 only $\$ 2,078$ million. It should also be noted that in 2012, foreign direct investment in financial activities and insurance amounted to 109,351 million dollars. However, in 2016 investments decreased 17 times, amounting to 18,649 million dollars [3]. Also a less attractive branch for foreign investors is "Information and Communication". In 2012, the amount was 5,891 million dollars, and in 2016 - fell to only $\$ 2,466$ million.

TABLE II. ATTRACTION OF FOREIGN DIRECT INVESTMENT BY ECONOMIC ACTIVITY (OFFICIAL WEBSITE OF THE WORLD BANK, 2016)

\begin{tabular}{|c|c|c|c|c|c|}
\hline Sectors & 2012 & 2013 & 2014 & 2015 & 2016 \\
\hline \multirow[t]{2}{*}{ Total,US Dollars Million } & 235 & 161 & 193 & 146 & 134 \\
\hline & 082 & 132 & 685 & 370 & 130 \\
\hline \multicolumn{6}{|l|}{ Including: } \\
\hline $\begin{array}{l}\text { Agriculture, forestry and } \\
\text { fishing }\end{array}$ & 667 & 656 & 934 & 598 & 671 \\
\hline Extraction of minerals & 16 & 15535 & 26 & 16 & 17 \\
\hline & 762 & & 155 & 339 & 426 \\
\hline Manufacturing industries & 25 & 32375 & 51 & 26 & 32 \\
\hline & 345 & & 750 & 741 & 013 \\
\hline Production and & 3 & 4000 & 2831 & 3 & 1120 \\
\hline $\begin{array}{l}\text { distribution of electricity, } \\
\text { gas, steam and air } \\
\text { conditioning }\end{array}$ & 297 & & & 251 & \\
\hline $\begin{array}{c}\text { Collection, purification } \\
\text { and distribution of water. } \\
\text { Collection of waste water, } \\
\text { waste and similar } \\
\text { activities }\end{array}$ & 18 & 22 & 28 & 14 & 27 \\
\hline Construction & $\begin{array}{c}5 \\
303 \\
\end{array}$ & 6756 & 5771 & $\begin{array}{c}4 \\
812 \\
\end{array}$ & 2078 \\
\hline Wholesale and retail trade & $\begin{array}{c}42 \\
295\end{array}$ & 42517 & $\begin{array}{c}43 \\
903\end{array}$ & $\begin{array}{c}32 \\
353\end{array}$ & $\begin{array}{c}37 \\
998\end{array}$ \\
\hline Transport and storage & $\begin{array}{c}4 \\
653\end{array}$ & 3237 & 2899 & $\begin{array}{c}3 \\
607\end{array}$ & 2262 \\
\hline $\begin{array}{l}\text { Activity of hotels and } \\
\text { restaurants }\end{array}$ & 373 & 472 & 332 & 386 & 461 \\
\hline $\begin{array}{l}\text { Information and } \\
\text { communication }\end{array}$ & $\begin{array}{c}5 \\
891\end{array}$ & 5623 & 5305 & $\begin{array}{c}3 \\
072 \\
\end{array}$ & 2466 \\
\hline Financial and insurance & 109 & 28690 & 31 & 31 & 18 \\
\hline activities & 351 & & 102 & 625 & 649 \\
\hline Real estate & $\begin{array}{c}7 \\
672\end{array}$ & 7637 & 7732 & $\begin{array}{c}7 \\
722\end{array}$ & 5789 \\
\hline $\begin{array}{c}\text { Scientific research and } \\
\text { development }\end{array}$ & 660 & 205 & 255 & 231 & 151 \\
\hline Education & 5 & 8 & 3 & 10 & 4 \\
\hline Health and social services & 310 & 482 & 446 & 341 & 139 \\
\hline Provision of other services & $\begin{array}{c}7 \\
233 \\
\end{array}$ & 9145 & 8685 & $\begin{array}{c}11 \\
056\end{array}$ & 9974 \\
\hline $\begin{array}{l}\text { Activities in the field of } \\
\text { leasing and leasing }\end{array}$ & 614 & 756 & 488 & 833 & 203 \\
\hline Unspecified & $\begin{array}{c}4 \\
631\end{array}$ & 3016 & 5065 & $\begin{array}{c}3 \\
381 \\
\end{array}$ & 2699 \\
\hline
\end{tabular}

Also the authors of the paper previously estimated a twofactor logarithmic model (Table 3), which shows the dependence of GRP per capita on the average monthly wage and total investment per capita [11].

TABLE III. RESULTS OF THE LOGARITHMIC REGRESSION EQUATION ASSESSMENT

\begin{tabular}{|c|r|r|r|r|}
\hline \multicolumn{5}{|c|}{ Dependent Variable: LN GRP } \\
\hline \multicolumn{5}{|c|}{ Method: Least Squares } \\
\hline \multicolumn{5}{|c|}{ Sample: 1 16 } \\
\hline Variable & Coefficient & Std. Error & t-Statistic & Prob. \\
\hline C & -4.104554 & 2.352662 & -1.744642 & 0.1046 \\
\hline SALARY & 1.294874 & 0.320976 & 4.034178 & 0.0014 \\
\hline INVEST & 0.323838 & 0.125025 & 2.590181 & 0.0224 \\
\hline R-squared & 0.879956 & Mean dependent var & 12.62303 \\
\hline Adjusted R-squared & 0.861488 & S.D. dependent var & 0.272614 \\
\hline S.E. of regression & 0.101459 & Akaike info criterion & -1.570956 \\
\hline Sum squared resid & 0.133822 & Schwarz criterion & -1.426096 \\
\hline Log likelihood & 15.56765 & F-statistic & 47.64693 \\
\hline Durbin-Watson stat & 2.339984 & Prob(F-statistic) & 0.000001 \\
\hline
\end{tabular}

Checking the statistical significance of the coefficients, we can safely note that in both cases Prob $<0.05$. Consequently, the coefficients are significant at the accepted level of reliability and the average monthly salary and total investments affect the GRP volume.

Estimating the calculated data of the table, we conclude that the coefficient of determination $\mathrm{R}=0.88$. In other words, in $88 \%$ of cases the changes in factors $\mathrm{X}$ lead to a change in $\mathrm{Y}$, and the share of residual, unaccounted factors in the model under consideration is $12 \%$. Consequently, the relationship between the factors is quite strong and this model demonstrates high quality. This is evidenced by the Fisher Prob (F-statistic), which shows a value of 0.000001 , illustrating the high reliability of this model. In addition, the analysis of the correlation matrix of both factors confirms the absence of multicollinearity (the value of the coefficient of pair correlation of the productive and factor characteristics is less than 0.70). The value of the Durbin-Watson statistic, close to 2 , indicates the lack of autocorrelation of the elements of the time series. This means that the constructed linear model of multiple regression probably reflects the real dependence. Most likely, there were no unaccounted significant factors affecting per capita GRP. In addition, the sufficiently high quality of the model is indicated by the acceptance of the put forward hypothesis of the homoscedasticity of the residues, i.e. the consistency of the variance of the residues, as evidenced by the White test, where the Prob F-statistics are 0.97 and Prob R2 $=0.952$, which indicates the validity of the null hypothesis on the homoscedasticity of the residues.

The multivariate model obtained by application package Eviews using the least-squares (OLS) method has the following form: 
$L N G R P=-4.10+1.29 * L N S A L A R Y+0.32 * L N I N V E S T+\varepsilon$.

$$
\text { (2.35) (0.32) }
$$

Equation (1) expresses the dependence of gross regional product (GRP) per capita on the average monthly salary (SALARY), the total investment per capita (INVEST). As the equation shows, with an increase in the average monthly salary and total investment per capita, the GRP per capita increases, and vice versa. In addition, we can say that with an increase in the average monthly salary by $1 \%$, the GRP per capita increases by an average of $1.29 \%$, all other things being equal. At the same time, with an increase in total investment per capita by $1 \%$, the GRP per capita increases by an average of $0.32 \%$, all other things being equal. The standard error for the coefficients for the variable SALARY is 0.32 , with the variable INVEST - 0.13 , for the free term - 2.35.

\section{FINDINGS}

Analyzing the above-mentioned facts, we can draw the following conclusions.

First, the dynamics of foreign direct investment in the period of 2012-2016 has a negative dynamics. There is a significant reduction in the volumes. In 2016, the total volume of foreign direct investment amounted to 134,130 million US dollars against 235,082 million US dollars in 2012.

Second, the most attractive industries for foreign investors are metallurgical and chemical production, retail and wholesale trade. Despite the relatively high share of these sectors in the structure of general foreign direct investment, their dynamics is unstable.

Third, investing in such sectors of economic activity as information and communication in recent years has not been an attractive direction for investors. Financial activity also became less attractive.

Thus, it can be said that the Russian economy is developing in conditions of a foreign investment lack. One of the reasons is the unfavorable environment for the implementation of the investment climate. Foreign investors may face a number of problems, primarily related to significant political, economic instability in the country, as well as high risks for foreign investors. To solve these problems, it is necessary to develop infrastructure, a high level of well-being and a significant share of the high-tech sector. Therefore, of course, the source of investment should be not only the funds of foreign companies, but internal reserves. Other reasons for the decline in the attractiveness of the Russian economy for foreign investors are the difficulty of running and opening own business, the high cost of borrowed funds, and the rather tight dependence of Russia on the cost of oil on the world market.

At the same time, it is necessary to emphasize the significance of foreign investment impact on the development of the real sector of the economy. It positively influences the technological development of the country as a whole, which is achieved through access to new technologies and management methods; increases tax revenues, which contributes to the expansion of public financing of the social sphere, increases the standard of living of the population; creates capital inflow to regions and areas with rich natural resources, which accelerates their development and use; expands the sales market; creates new jobs and increased demand for labor; creates additional incentives for other investors, which increases confidence in the national economy, etc.

However, there are negative aspects of attracting foreign investment. They are the following: the loss of state control over part of the national production; ousting domestic capital by foreign investments; the expectation of deterioration of the environmental situation in the country; increase in structural unemployment; the loss risks occurrence, in which the exported capital out of the country exceeds the invested foreign investment; the growth of social inequality.

\section{CONCLUSION}

Thus, foreign investment is an important element in the development of the real sector of the economy. However, at the moment Russia is one of the less attractive countries for investing foreign capital for a number of reasons. The impact of foreign investment on the national economy can change it in accordance with the objectives of foreign investors, and they may not coincide with the objectives of the recipient country. Therefore, it is necessary not only to pursue an effective investment policy, but also to regulate the inflow of foreign investment at the legislative level, to develop and create new programs of interaction with foreign investors, taking account the long-term nature of their investment. Only in this case there will be a positive effect, a stable investment climate and the successful development of the domestic economy.

\section{References}

[1] N. Fabry, S. Zeghni, "Foreign direct investment in Russia: how the investment climate matters". Communist and Post-Communist Studies 35, Issue 3, pp.289-303, 2002

[2] I. Filatotcheva, M. Wrightb, K. Uhlenbruckc, L. Tihanyid, R. E. Hoskissond. "Governance, organizational capabilities, and restructuring in transition economies". Journal of World Business 38, Issue 4, pp.331347,2003

[3] A.S. Gizyatova, "Audit as one of the mechanisms of combating corruption", Ufa State Petroleum Technological University. pp.53-56, 2014 [Modern trends in economics and finance: Proceedings of the fourth All-Russian Scientific and Practical Conference, pp.53-56, 2014].

[4] A.G. Granberg, N.N. Miheeva, N.M. Ibragimov, V.I. Suslov, T.S. Novikov, "The results of experimental calculations to assess the effectiveness of investment projects using interbranch interregional models", Region: Economics and Sociology, vol. 4, pp.238-240, 2010

[5] A.G. Granberg, N.N. Miheeva, V.I. Suslov, U.S. Ershov, "Economicmathematical studies of spatial development of Russia on the basis of interbranch models", Moscow: IMEI, pp.63-66, 2011 [Proceedings of International Conference: Interindustry balance: history and prospects. pp.63-66, 2011]

[6] I.P. Gurova, "Foreign direct investment and globalization of the economy", Symbol of science, vol.10-1(22), pp.56-60, 2016.

[7] V.V.Ivanter, D.R. Belousov, A.A. Blohin, "Structural and investment policy for sustainable growth and modernization of the economy". Scientific report. Institute of Economic Forecasting Russian Academy of Sciences, p. 34, 2017. 
[8] K. A. Khubiev, "Investment crisis of the Russian economy: reasons, ways to overcome", 2009, Retrieved from: www.alternativy.ru/old/magazine/htm/963/investit.htm

[9] I.U. Koval, "Foreign direct investment: a logistical assessment of the vector of structural restructuring of sectoral investments", Integral, vol.6, pp.66-68, 2011.

[10] R. M. Kundakchyan, T.M. Vakhitova, L.A. Gadelshina, L.F. Garifova, L.F. Zulfakarova, "Empirical analysis of the direct foreign investment's influence on the structural shifts in the region's economy", pp. 255-262, 2017 [International multidisciplinary scientific conference Social sciences \& arts SGEM, pp. 255-262, 2017].

[11] R. M. Kundakchyan, T.M. Vakhitova, L.A. Gadelshina, L.F. Garifova, L.F. Zulfakarova, "Evaluation of the influence of factors of the regional economic development on the gross regional product", National academy of managerial staff of culture and arts. 4, pp.280-284, 2017.

[12] B.T. Kuznetsov, Investment, Moscow: Unity-Dana, 2012, pp.560-567.
[13] B.T. Kuznetsov, Economics and financial support of innovation activities. Moscow: Unity-Dana, 2011, pp.112-123.

[14] Official site of world bank. Economy rankings, 2018. Retrieved from: http://russian.doingbusiness.org/rankings

[15] Official site of A.T. Kearney consulting firm, 2017. Retrieved from: https://www.atkearney.com

[16] B.K. Sabanichev, "Classification of sources of investment and its applications in accounting for the investment and construction holding company", Economic and Law Issues, Vol.12, pp.352-356, 2010.

[17] World Bank Group. Doing Business 2016: Measuring Regulatory Quality and Efficiency, Washington, DC: World Bank, 2016. Retrieved from: https://openknowledge.worldbank.org/handle/10986/22771

[18] E. Yasara, S. Acıkalınb, A. Gezera, “Testing IDP Hypothesis by Cluster Analysis: Which Countries in Which Stage?" Procedia Economics and Finance, vol. 23, pp.1201-1209, 2015. 